Jurnal Riset Manajemen Dan Akuntansi

Volume 1- No. 2, Oktober 2014

\title{
PENGARUH TARIF IKLAN TERHADAP PENDAPATAN PADA PT. RADIO SWARA CARANO BATIRAI INDAH BATUSANGKAR
}

\author{
Febsri Susanti \\ STIE “KBP” Padang \\ (Febsri26@gmail.com)
}

\begin{abstract}
This Reserch aims to know the influence of Variable rate prices against revenue on PT. Radio Swara Carano Batirai Indah Indah Batusangkar. The type of research used in this writing is field reseach which are quantitatively at PT. Radio Swara Carano Batirai Indah Batusangkar. Technique Of Data analysis is by using simple regreression analysis. The results showed thet the relationship with rates revenues hane a strong relationship. This is evidenced by the specified rates of PT. Radio Swara Carano Batirai Indah Batusangkar have a strong relationships are characterized by values of $r$ $=0,902$ so $r^{2}=0,812$ means that revenue is influenced by advertising rates amounting to $81 \%$ while $19 \%$ are influenced by other factors.
\end{abstract}

Keywords :rate prices, revenue

\section{PENDAHULUAN}

Dengan adanya tarif spot iklan yang ditetapkan tiap tahun maka akan mempengaruhi jumlah spot iklan yang diminta klien tergantung berapa spot klien ingin mempromosikan iklannya dan iklan dalam bentuk informasi tergantung pada acara tersebut terselenggara. Permintaan atau demand konsumen merupakan suatu aspek yang sangat penting dalam ekonomi manajerial, karena suatu perusahaan tidak akan pernah ada dan berkembang dengan pesat jika permintaan terhadap produknya tidak ada. Demikian juga dalam hal penyiaran iklan dalam radio. Tarif tentunya berpengaruh terhadap permintaan penyiaran iklan, dan akan berpengaruh terhadap pendapatan iklan pada radio tersebut.

Berdasarkan data terdapat peningkatan tarif iklan per spot tiap tahunnya adalah sebesar Rp 100 s/d Rp
500 yang diiringi juga dengan meningkatnya permintaan iklan setiap tahunnya dan juga berpengaruh terhadap pendapatan secara fluktuatif. Karena untuk pendapatan PT. Radio Swara Carano Batirai Indah Batusangkar ini tidak seluruhnya berasal dari iklan, ada sumber pendapatan lain yang diterima oleh PT. Radio Swara Carano Batirai Indah Batusangkar misalnya melalui acara on air debat caleg, lomba mubaligh cilik. Dalam hal ini PT. Radio Swara Carano Batirai Indah Batusangkar adalah sebagai fasilitator yang akan mendapat fee dari acara tersebut yang diakui sebagai pendapatan. Dari latar belakang tersebut penulis tertarik untuk meneliti seberapa besar pengaruh tarif iklan terhadap pendapatan PT. Radio Swara Carano Batirai Indah Batusangkar dan penulis menuangkan dalam skripsi dengan judul: Pengaruh Tarif Iklan 
Terhadap Pendapatan Pada PT. Radio Swara Carano Batirai Indah Batusangkar.

\section{KERANGKA TEORITIS DAN PERUMUSAN HIPOTESIS}

Media iklan adalah segala sarana komunikasi yang dipakai untuk mengantarkan dan menyebar-luaskan pesan-pesan iklan. Pada prinsipnya, jenis media iklan dalam bentuk fisik dibagi kedalam dua kategori yaitu: media iklan cetak dan media iklan elektronik. Media iklan cetak adalah media cetak yang memuat iklan sedangkan media iklan elektronik adalah media elektronik yang memuat iklan.

Media cetak adalah media statis dan mengutamakan pesan-pesan visual yang dihasilkan dari proses percetakan, bahan baku dasarnya maupun sarana penyampaian pesannya menggunakan kertas. Media cetak adalah suatu dokumen atas segala hal tentang rekaman peristiwa yang diubah dalam kata-kata, gambar foto dan sebagainya. Contoh media cetak adalah: surat kabar, majalah, tabloid, brosur, pamflet, poster. Sedangkan media elektronik adalah media yang proses bekerjanya berdasar pada prinsip elektronik dan eletromagnetis (contoh televisi, radio, internet). Diantara dikotomi media tersebut ada satu media yang tidak termasuk dalam kategori keduanya yaitu media luar ruang (papan iklan atau billboard)

\section{Tujuan Media Iklan}

Ada banyak pendapat tentang fungsi dan tujuan iklan. Iklan menjadi sangat penting untuk berkomunikasi antara perusahaan atau produsen dengan masyarakat. Secara umum, iklan memiliki fungsi dan tujuan sebagai berikut:

\section{Memberikan informasi}

Dengan iklan, khalayak atau masyarakat diberi informasi mengenai produk atau merek tertentu. Selain itu, dengan iklan, masyarakat atau khalayak diberi informasi mengenai karakteristik serta keunggulan suatu produk atau merek tertentu. Dengan demikian, iklan dapat membuat konsumen atau calon konsumen sadar akan adanya produk baru. Pada tahap awal produk, iklan sangat diperlukan untuk membangun permintaan primer. Jadi, iklan merupakan bentuk komunikasi yang efisien karena mampu meraih khalayak luas dengan biaya yang relatif rendah.

\section{Membujuk}

Iklan juga berfungsi untuk membujuk khalayak atau masyarakat agar tetap menggunakan atau memakai atau mengkonsumsi produk atau merek tersebut. Hal ini sangat penting, terutama pada tahap persaingan dimana perusahaan ingin membangun permintaan selektif untuk produk tertentu. Beberapa iklan menggunakan comparative advertising yang memberikan perbandingan atribut dari dua atau lebih merek atau produk secara eksplisit. Iklan yang efektif akan membujuk konsumen atau calon konsumen untuk mencoba menggunakan atau mengkonsumsi suatu produk. Kadang-kadang iklan dapat mempengaruhi permintaan primer yang membentuk permintaan untuk seluruh kategori produk. Seringkali iklan juga ditujukan untuk membangun permintaan sekunder yaitu permintaan untuk merek perusahaan tertentu.

\section{Mengingatkan}

Iklan juga dapat membuat konsumen tetap ingat pada merek atau produk perusahaan. Ketika timbul 
kebutuhan yang berkaitan dengan produk tertentu, konsumen akan mengingat iklan tentang produk tertentu. Maka konsumen tersebut akan menjadi kandidat pembeli. Jadi, iklan juga bertujuan untuk mengingatkan khalayak atau masyarakat sebagai konsumen atau calon konsumen terhadap produk tertentu.

\section{Memberikan nilai tambah}

Iklan juga dapat memberikan nilai tambah terhadap produk atau merek tertentu dengan cara mempengaruhi persepsi konsumen. Iklan yang efektif akan memberikan nilai tambah produk sehingga produk dipersepsikan lebih mewah, lebih bergaya, lebih bergengsi, bahkan melebihi apa yang ditawarkan oleh produk lain, dan secara keseluruhan memberikan kualitas yang lebih baik dari produk lainnya.

5. Mendukung usaha promosi lainnya Iklan juga dapat digunakan sebagai alat pendukung usaha promosi lainnya seperti sebagai alat untuk menyalurkan sales promotion, pendukung sales representative, meningkatkan hasil dari komunikasi pemasaran lainnya.

Disamping itu, menurut Tellis (1998) periklanan memberikan dampak terhadap produksi massal dibutuhkan perusahaan untuk melayani pasar yang luas. Perusahaan harus memberi merek produknya dengan nama yang unik sehingga konsumen melakukan permintaan terhadap suatu barang tertentu.

Jadi, produksi massal dan pemasaran dapat menguntungkan bila telah memiliki merek. Produksi massal membutuhkan kemasan yang baik. Sehingga perusahaan dapat memberi merek pada kemasan dengan desain dan nama yang unik. Oleh karena itu iklan merupakan alat komunikasi perusahaan terhadap konsumen untuk menyampaikan kualitas produk yang unik yang dapat dilihat dari kemasan unik dan merk produk yang dihasilkan.

Fungsi iklan adalah :Iklan sebagai pemberi informasi tentang produk yang ditawarkan dipasar dan iklan sebagai pembentuk pendapat umum tentang sebuah produk.Persoalan etis dalam iklan:

1. Iklan merongrong otonomi dan kebebasan manusia.

2. Iklan yang manipulatif dan persuasif non-rasional menjadikan manusia yang konsumtif.

3. Iklan merongrong rasa keadilan social dan memicu kesenjangan social.

\section{Pendapatan}

Pendapatan menurut ilmu ekonomi merupakan nilai maksimum yang dapat dikonsumsi oleh seseorang dalam suatu periode dengan mengharapkan keadaan yang sama pada akhir periode seperti keadaan semula. Pengertian tersebut menitikberatkan pada total kuantitatif pengeluaran terhadap konsumsi selama satu periode. Dengan kata lain, pendapatan adalah jumlah harta kekayaan awal periode ditambah keseluruhan hasil yang diperoleh selama satu periode, bukan hanya yang dikonsumsi.

Definisi pendapatan menurut ilmu ekonomi menutup kemungkinan perubahan lebih dari total harta kekayaan badan usaha pada awal periode, dan menekankan pada jumlah nilai statis pada akhir periode. Secara garis besar pendapatan adalah jumlah harta kekayaan awal periode ditambah perubahan penilaian yang bukan diakibatkan perubahan modal dan hutang.

Karekteristik pendapatan: Selisih dari keduanya nantinya menjadi laba atau income dan rugi atau less, Pendapatan dari kegiatan normal perusahaan biasanya diperoleh dari hasil 
penjualan barang ataupun jasa yang berhubungan dengan kegiatan utama perusahaa, Ada beberapa karakteristik tertentu dari pendapatan yang menentukan atau membatasi bahwa sejumlah rupiah yang masuk ke perusahaan merupakan pendapatan yang berasal dari operasi perusahaan. Karakteristik ini dapat dilihat berdasarkan sumber pendapatan, produk dan kegiatan utama perusahaan dan jumlah rupiah pendapatan serta proses penandingan.

\section{Tarif Iklan}

Dalam teori media dan masyarakat masa dikatakan bahwa media memiliki asumsi untuk untuk membentuk masyarakat yakni:Media massa memiliki efek yang berbahaya bagi masyarakat. Tahun 1920-an di Eropa, penyiaran dikendalikan oleh pemerintah. Hal ini berdampak buruk dijerman karena digunakan untuk propaganda Nazi.Media massa memiliki kekuatan untuk mempengaruhi pola pikir audiennya.

Rata-rata orang yang terpengaruh oleh media dikarenakan mengalami keterputusan dengan institusi social yang sebelumnya melindungi dari efek negaatif media. Jhon Dewei berkata bahwa efek negative media dapat disaring melaui pendidikan.

Sejak tahun 20.000 SM manusia sudah menemukan media untuk berkomunikasi dalam bentuk pahatan didinding gua atau asap api. Tahun $1.500 \mathrm{M}$ Johanes Gutenberg memperkenalkan mesin cetak. Di Indonesia radio merupakan alat komunikasi penting sejak berdirinya negara ini. Radio digunakan secara luas di bidang pendidikan terutama pendidikan politik seperti mempersiapkan para calon pemilih untuk pemilu pertama tahun 1955. pada masa orde baru terdapat 39 stasiun RRI diseluruh Indonesia.

Seen dan Hill mengatakan bahwa radio juga signifikan dalam melegitimasi kenaikan Soeharto ketumpuk kekuasan tahun 1965. Pada masa itu banyak orang mengoperasikan radio dari rumah secara pribadi. Sebagian diantaranya menjadi lebih sifat politik setelah insiden 1 oktober 1965 dan memilik staf yang terdiri dari sekelompok aktifis mahasiswa yang menentang Persiden Soeharto.Yang paling terkenal adalah Radio Ampera yang didirikan para aktivis mahasiswa termasuk kakak beradik Soe Hok Gie dan Arif Budiman. Mereka siaran dari rumah Mashuri, tetangga dan orang terpercaya Soeharto.

Dengan demikian media memperluas komunikasi manusia dalam hal produksi dan distribusi pesan, menerima menyimpan dan menggunakan kembali informasi. Produksi meliputi penciptaan pesan menggunakan media komunikasi, sedangkan distribusi meliputi tranmisi (memindahkan pesan), reproduksi yang diikuti amplifikasi (penjelasan) pesan, display (membuat pesan tampak nyata secara fisik ketika sampai ke tujuan. Studi tentang penyiaran sebagai komunikasi massa meski pula dilihat berbagai teori tentang efek komunikasi massa.

Untuk lebih mengenal media penyiaran beberapa istilah yang diambil dari UU Penyiaran No. 32 Tahun 2002 berikut ini bisa menjadi acuan :

Siaran adalah pesan atau rangkaian pesan dalam bentuk suara, gambar, atau suara dan gambar atau yang berbentuk grafis, karakter, baik yang bersifat interaktif maupun tidak, yang dapat diterima melalui perangkat penerima siaran (Pasal 1:1) 
Penyiaran adalah kegiatan pemancarluasan siaran melalui sarana pemancaran dan/atau sarana transmisi di darat, di laut atau di antariksa dengan menggunakan spektrum frekuensi radio melalui udara, kabel, dan/atau media lainnya untuk dapat diterima secara serentak dan bersamaan oleh masyarakat dengan perangkat penerima siaran (Pasal 1:2)

Penyiaran radio adalah media komunikasi massa dengar, yang menyalurkan gagasan dan informasi dalam bentuk suara secara umum dan terbuka, berupa program yang teratur dan berkesinambungan (Pasal 1:3)

Penyiaran televisi adalah media komunikasi massa dengar pandang, yang menyalurkan gagasan dan informasi dalam bentuk suara dan gambar secara umum, baik terbuka maupun tertutup, berupa program yang teratur dan berkesinambungan (Pasal $1: 4)$

Lembaga penyiaran adalah penyelenggara penyiaran, baik lembaga penyiaran publik, lembaga penyiaran swasta, lembaga penyiaran komunitas maupun lembaga penyiaran berlangganan yang dalam melaksanakan tugas, fungsi, dan tanggung jawabnya berpedoman pada peraturan perundangundangan yang berlaku (Pasal 1:9).

Jasa Penyiaran di Indonesia terdiri atas jasa penyiaran radio; dan jasa penyiaran televisi. Jasa penyiaran ini (Pasal 13 :2) diselenggarakan oleh Lembaga Penyiaran Publik adalah lembaga penyiaran yang berbentuk badan hukum yang didirikan oleh negara, bersifat independen, netral, tidak komersial, dan berfungsi memberikan layanan untuk kepentingan masyarakat (Pasal $14: 1$ ), yang terdiri atas Radio Republik Indonesia dan
Televisi Republik Indonesia yang stasiun pusat penyiarannya berada di ibukota Negara Republik Indonesia (Pasal 14 :2) dan Lembaga Penyiaran Swasta adalah lembaga penyiaran yang bersifat komersial berbentuk badan hukum Indonesia.

Sedangkan dalam defenisi lain pengertian siaran, penyiaran serta perbedaan antara penyiaran radio dengan penyiaran televisi. Dalam buku Komisi Penyiaran Indonesia Berdasarkan Keputusan Komisi Penyiaran Indonesia Nomor 009/SK/KPI/8/2004 Tentang Pedoman Prilaku Penyiaran Dan Standar Program Siaran. Siaran adalah pesan atau rangkaian pesan dalam bentuk suara, gambar, atau suara dan gambar atau yang berbentuk grafis, karakter, baik yang bersifat interaktif atau tidak yang dapat diterima melalui perangkat penerima siaran. Penyiaran adalah kegiatan pemencarluasan siaran melalui sarana pemencaran dan atau sarana tranmisi didarat, dilaut atau diantariksa dengan menggunakan spektrum frekuensi radio melaui udara, kabel dan atau media lainnya untuk dapat diterima secara serentak dan bersamaan dan oleh masyarakat dengan perangkat penerima siaran.

Perbedaan antara penyiaran radio dengan penyiaran televisi adalah penyiaran televisi adalah media komunikasi massa dengar pandang, yang menyalurkan gagasan dan informasi dalam bentuk suara dan gambar secara umum baik terbuka maupun tertutup berupa program yang teratur dan berkesinambungan. Sedangkan penyiaran radio adalah media komunikasi massa dengar yang menyalurkan gagasan dan informasi dalam bentuk suara secara umum dan terbuka berupa program yang teratur dan berkesinambungan. 
Tarif dalam penertian sehari-hari sering diartikan sama dengan harga atau price yang didefenisikan sebagai nilai jasa. Sebenarnya pengertian tarif tidaklah sama dengan harga. Pegertian tarif lebih terkait pada besarnya biaya yang harus dikeluatrkan untuk memperoleh jasa pelayanan, sedangkan penegertian harga lebih terkait pada besarnya biaya yang harus dikeluarkan untuk memperoleh barang.

\section{HIPOTESIS}

Ho : Tidak ada pengaruh yang signifikan antara tarif iklan terhadap pendapatan PT.Radio Swara Carano Batirai Indah Batusangkar

Ha : Adanya pengaruh positif antara tarif iklan terhadap pendapatan PT.Radio Swara Carano Batirai Indah Batusangkar secara signifikan.

\section{METODOLOGI}

Jenis penelitian yang penulis gunakan dalam penelitian ini adalah field research/ penelitian lapangan yang bersifat deskriptif, yaitu menggambarkan tentang pengaruh tarif iklan terhadap pendapatan pada PT. Radio Swara Carano Batirai Indah Batusangkar.

Tehknik yang penulis pakai dalam mengumpulkan data adalah dokumentasi dan wawancara dengan pihak PT.Radio Swara Carano Batirai Indah Batusangkar. Sumber data yang penulis ambil adalah berupa data primer yaitu data pokok berupa laporan perkembangan tarif iklan per spot terhadap pendapatan dalam satu periode yang penulis peroleh dari pihak PT. Radio Swara Carano Batirai Indah Batusangkar dan data sekunder yaitu berupa wawancara dengan pihak dan PT. Radio Swara Carano Batirai Indah Batusangkar bagian marketing dan kepala studio.

\section{HASIL DAN PEMBAHASAN}

Nilai $\mathrm{r}^{2}$ atau koofisien determinan $=$ 0,814 atau $81 \%$ artinya pendapatan PT. Radio Swara Carano Batirai Indah Batusangkar dipengaruhi $81 \%$ oleh tarif iklan lokal sedangkan $19 \%$ lainnya dipengaruhi oleh faktor-faktor lainnya.

Berdasarkan pengolahan data yang penulis lakukan maka hasil perhitungan $\mathrm{y}=-159008230+68700,194 \mathrm{x}$ artinya apabila terdapat penambahan tarif iklan sebanyak 1 maka akan meningkatkan pendapatan iklan lokal sebesar 68700,194 . Namun pada saat tidak dilakukan penentuan tarif iklan maka pendapatan iklan lokal adalah 159008230.

Dari analisis regresi besarnya pengaruh penentuan tarif terhadap pendapatan iklan dimana setiap penambahan Rp 1,tarif dalam satu spot maka akan meningkatkan pendapatan sebesar 68700,194 .

Pengujian hipotesa dengan menggunakan T.Test diperoleh To $=$ 5,914 sedangkan nilai kritis menurut tabel, dengan rumus $\mathrm{t} \alpha / 2 \mathrm{db} n-2$ yaitu $0,05 / 2 \mathrm{db} 10-2=2,306$. Karena to $(5,914)$ lebih besar dari t tabel pada taraf signifikan 0,05 maka Ha diterima, artinya adanya pengaruh tarif iklan lokal terhadap pendapatan iklan lokal pada PT. Radio Swara Carano Batirai Indah Batusangkar secara signifikan.

\section{SIMPULAN DAN SARAN}

Dari hasil penelitian diatas dapat diambil kesimpulan hubungan antara tarif iklan dengan pendapatan mempunyai hubungan yang kuat pada PT. Radio Swara Carano Batirai Indah Batusangkar, ini dibuktikan dengan nilai $\mathrm{r}=0.902$ dan nilai koofisien determinan atau $r^{2}=0.814$ artinya pendapatan dipengaruhi oleh tarif iklan 
sebesar $\quad 81 \% \quad$ sedangkan $19 \%$ dipengaruhi oleh faktor-faktor lainnya.

Berdasarkan hasil penelitian dan olahan data yang penulis lakukan disarankan kepada PT. Radio Swara Carano Batirai Indah Batusangkar untuk menentukan tarif iklan dalam satu spot iklan yang tidak terlalu tinggi mengingat persaingan di kota Batusangkar yang telah mempunyai 3 stasiun radio agar pendapatan iklan PT. Radio Swara Carano Batirai Indah meningkat. Tetap melakuakan variasi dalam iklan lokal agar permintaan iklan lokal meningkat yang pada akhirnya dapat meningkatkan pendapatan PT. Radio Swara Carano Batirai Indah Batusangkar.

\section{DAFTAR PUSTAKA}

Drs. Iswardono SP MA, 2004, Ekonomika Mikro, Yogyakarta: UPP AMP YKPN.

Dukat, Erwan.1986. Accounting theory (teori akuntansi). Yogyakarta: AK Group.

J. Supranto, 2000. Statistik Teori Dan Aplikasi, (Jakarta: Erlangga.

Karim, Adiwarman A. 2007. Ekonomi Mikro Islami. Jakarta: PT Raja Grafindo Persada.

Komisi Penyiaran Indonesia. Keputusan Komisi Penyiaran Indonesia Nomor 009/SK/KPI/8/2004 Tentang Pedoman Prilaku Penyiaran Dan Standar Program Siaran.

Nasution, Mustafa Edwin,dkk, 2006. Pengenalan Eksklusif Ekonomi Islam, Jakarta: Kencana Prenada Media Grup, 2006.

Pusat Pengkajian dan Pengembangan Ekonomi Islam (P3EI) Universitas Islam Indonesia Yogyakarta atas kerja sama dengan Bank Indonesia.2008.
Ekonomi Islam.(Jakarta: PT. Raja Grafindo Persada.

Musselman, Vernon A. dan Jhon H. Jackson, 2009. Pengantar Ekonomi Perusahaan,Jakarta: Erlangga.

Singian,DergibsonMetode Statistik Untuk BIsnis Dan Ekonomi, 2002. Jakarta: PT. Gramedia Pustaka Utama.

Suprayitno, Eko. 2008. Ekonomi Mikrio Perspektif Islam. Yogyakarta: UIN-MALANG PRESS.

Tim Penyusun Kamus Pusat Pembinaan dan Pengembangan Bahasa, 1995. Kamus Besar Bahas Indonesia, Jakarta: Balai Pustaka, Edisi ke 2, cet 4

Yusanto, Muhammad Imail dan Muhammad Karebet Widjajakusuma, 2002. Menggagas Bisnis Islami, Jakarta: Gema Insani.

http://etd.eprints.ums.ae.id/5779/1/B100 040354.pd4

http://puslit.petra.ac.id/journals/design/

http://edwi.dosen.upnyk.ac.id/MED.IK $\underline{\text { LAN.7.doc }}$

http://resources.unpad.ac.id/unpadcontent/uploads/publikasi_dosen/ 
JURMAK, Vol.1, No. 2, Oktober 2014:235-241 